\section{EDWIN KLEBS (1834-1913)}

WiтH the death of Edwin Klebs at Bern, Switzerland, on October 25, 1913, there passed away the last of the great pioneers of the bacterial theory of infection, a pupil of Virchow, a contemporary of Pasteur and, in a very definite sense, the inspirer of Koch. Born at Königsberg in 1834, Klebs was an East Prussian and the peculiar effect of his character upon his work, a certain discontinuity in the latter, was due to the Slavic element in his composition. He was a peripatetic all his life and, after serving as Virchow's assistant at Berlin (1861-66), he was successively professor of pathology at Bern (1866), Würtzburg (1872), Prague (1873), Zurich (1882) and Chicago (Rush Medical College, 1896), after which he lived in retirement at Dortmund and Bern. During all this time he was a prominent worker in all branches of pathology and in the truest sense a precursor in the bacterial theory of disease. Indeed, his greatest service to medicine was, perhaps, the important influence he exerted upon the pathologists of his time, leading them away from the solidist theories of Virchow and winning them over to the view that post-mortem findings are only end results and that infectious diseases are caused by microorganisms and their chemical products. Koch himself admitted, in a private letter, that he owed much to Klebs, who had been the actual path-breaker in many of the new fields followed by the younger men. Up to 1876 , Klebs was the leading protagonist of the modern theory of specific infections (Pasteur did not begin to work in anthrax until about 1880), and, by actual priority of publication, he preceded Koch in the study of bacterial wound infections (1871) and in the technique of growing bacterial cultures in special media (hens' eggs in the first instance). During his Würzburg period, his idea of obtaining pure cultures of pathogenic microorganismś was actually laughed at as an idle dream. Long before Pasteur and Joubert, he showed that the blood of anthrax is not pathogenic after filtration (1871); in other words that the virus of the disease is non-filterable. From this idea, it was but a step for Loeffler to reason and to prove that diseases may be caused by "filterable viruses". (1898). Klebs saw the typhoid bacillus before Eberth (1881), the diphtheria bacillus before Loeffler (1883), investigated the tubercle bacilli of cold-blooded animals and their therapeutic possibilities before Friedmann (1900), inoculated monkeys with syphilis before Metchnikoff (1878), first investigated the bacteriology of gun-shot wounds (1872), first produced bovine infection of Perlsucht by feeding with milk (1873), first investigated the infectious nature of endocarditis (1878), and made the first exhaustive study of acromegaly (1884). Meanwhile, his two pathological treatises of $1869-76$ and 1887-89 were acknowledged masterpieces in the older field of descriptive or morphological pathology, of which he was the leading exponent after Rokitansky and Virchow and in which Chiari is one of the few surviving workers. Klebs's definite abandonment of the solidist or "end result" pathology dates from his discourses of 1878 and 1882, which are definitely contra-Virchow, although nothing could be more courteous and reasonable than his attitude in joining issue with his old teacher and friend. In bringing the weak-kneed over to the modern view, his propagandism was of the broadest and most impersonal character. After 1876-8, Klebs's work was definitely overshadowed by Koch's great papers on anthrax and the traumatic infectious diseases, and his influence began to wane. It may be asked, why did this remarkable man not reap the fruits of his brilliant labors? Why is he not better known to-day? Some may find the answer in Lord Woolsey's dictum that "he alone is a good general who follows up his victories." But this reproach can not entirely be cast up to Klebs. His work was constantly interrupted by such occurrences as the revolution in Prague and the intrigues and internecine wrangles which sometimes go on among university professors. His temperament was restless, sensitive, impulsive and combative, and, being wrapped up in the original ideas which were always coming to him, he had a tendency to leave work of an important character to his assistants, which was not to his advantage. 
Some of his ideas about infection, e. g., his "bacillus malariæ," his " microzoon septicum". (wound infections), his "monadines" (rheumatic affections), turned out to be wrong, and where he struck into some good lead, as in diphtheria or typhoid, he was perhaps for this very reason little inclined to follow it up. Yet, all in all, Klebs was one of the most original spirits in modern medicine, a man who paid dearly for his unshakable confidence in humanity and his tendency to fight in the open, an opponent who soon forgot differences with his fellows and never cherished ill-will. He will remain where Osler has placed him as a great pioneer. He had a prophetic vision into the future and a fine historic sense, looking, as Wordsworth said of the poet, "before and after." His discourse on the history of medicine, delivered at Bern in 1868, may be likened to the little book of Stopford Brooke on Engish literature, as being the most delightful primer of the subject (as dissociated from surgery and the specialties) ever written. It deserves to be translated. Klebs was a founder and co-editor of the Correspondenzblatt für schweizerische Aerzte (1871), the Prager medicinische Wochenschrift (1876), and he was, with Naunyn and Buchheim, a founder and for many years co-editor of the important Archiv für experimentelle Pathologie und Pharmakologie (1872). Naunyn, the distinguished clinician of Strassburg, who was Klebs's colleague at Bern, refers to him in the following terms :

Ein langes Leben reich an Arbeit und an Unruhe. Wie er es sich selbst geschaffen, so hat er es hingenommen, ohne sich beugen zu lassen, ein aufrechter Mann bis an seinen Tod. Uns, seinen Freunden aus alter Zeit, sind sein offener Sinn, sein sprühender, anregender Geist, sein warmes Herz eine liebe, dankbare Erinnerung.

\section{F. H. GARRISON}

\section{ARMy Medical MUSEUm}

\section{SCIENTIFIC NOTES AND NEWS}

THe annual meeting of the Physical Society will be held in Atlanta, Ga:, December 29January 3, the society meeting in joint session with Section B of the American Association for the Advancement of Science. The place of meeting will probably be the Georgia School of Technology. The program of ordinary technical papers will be in charge of the Physical Society, but two, or perhaps three, sessions will be in charge of Section B. These will be devoted to papers of general scientific interest, relating especially to some of the larger problems of geophysics. The program of the meeting will include the address of the president of the Physical Society, Professor B. O. Peirce, and that of the retiring vice-president of Section B, Professor A. G. Webster.

M. Paul OtLet, of Brussels, sécretaire de la Union des Congréses Internationales, who represented the Union at the Dundee meeting of the British Association for the Advancement of Science, will be present at the Atlanta meeting of the American Association for the Advancement of Science and will address the association on the subject of the international organization of scientific activities.

THE meeting of the Paleontological Society at Princeton will include a symposium on "The Close of the Cretaceous and Opening of Eocene in North America" with an introduction by Professor H. F. Osborn and Messrs. F. H. Knowlton, T. W. Stanton, W. J. Sinclair and Barnum Brown leading the discussion.

Fon the Australian meeting of the British Association in August next year, under the presidency of Professor W. Bateson, F.R.S., the following presidents of sections have been appointed:

Section A (Mathematics and Physics), Professor F. T. Trouton.

Section B (Chemistry), Professor W. J. Pope.

Section C (Geology), Sir T. H. Holland.

Section D (Zoology), Professor A. Dendy.

Section E (Geography), Sir C. P. Lucas.

Section F (Economies), Professor E. C. K. Gonner.

Section G (Engineering), Professor E. G. Coker. Section H (Anthropology), Sir Everard im Thurn. Section I (Physiology), Professor C. J. Martin. Section K (Botany), Professor F. O. Bower.

Section L (Educational Science), Professor J. Perry.

Section M (Agriculture), Mr. A. D. Hall. 